\title{
POLITIK SUMBER DAYA ALAM: STUDI TERHADAP KEPENTINGAN ELIT \\ POLITIK LOKAL DALAM PEMEKARAN WILAYAH DI KABUPATEN PASER PROVINSI KALIMANTAN TIMUR
}

\author{
Niken Nurmiyati, Dian Eka Rahmawati, dan David Efendi \\ Magister Ilmu Pemerintahan Universitas Muhammadiyah Yogyakarta, Bantul, Indonesia \\ E-mail: nikennurmia@gmail.com
}

\begin{abstract}
ABSTRAK. Penelitian ini berupaya untuk mengkaji tentang politik sumber daya alam dalam kaitannya dengan kepentingan elit politik lokal pada pemekaran wilayah di Kabupaten Paser. Metode yang digunakan adalah kualitatif yang didukung oleh software NVivo 12 Plus melalui coding data pada situs berita online. Hasil penelitian menyatakan bahwa elit politik lokal memiliki peran dalam proses pemekaran wilayah, mulai dari Bupati hingga anggota DPR RI. Dominasi kepentingan politik semakin kentara ketika isu pemekaran mulai bermunculan, mulai dari DOB Paser Tengah dan DOB Paser Selatan. Keduanya sama-sama mengusulkan pemekaran. Sebagai wilayah administratif pemekaran, Kecamatan Batu Sopang dan Muara Komam memiliki kedudukan strategis karena memiliki SDA yang melimpah terutama tambang batu bara serta hasil perkebunan dan pertanian. Awalnya kedua kecamatan tersebut memilih bergabung menjadi DOB Paser Tengah, namun karena dominasi elit lokal dalam memainkan strategi politik, maka kedua kecamatan tersebut memisahkan diri dari Paser Tengah dan bergabung menjadi DOB Paser Selatan. Atas fakta tersebut, maka Paser Selatan yang berhasil mendapatkan rekomendasi pemekaran. Hingga saat ini proses pemekaran Paser Selatan telah sampai pada tahap Prolegnas. Namun masih terhenti sementara karena adanya kebijakan Moratorium dari Pemerintah Pusat.
\end{abstract}

Kata kunci: Pemekaran Wilayah; Elit Lokal; Sumber Daya Alam

ABSTRACT. This study seeks to examine the politics of natural resources in relation to the interests of the local political elit in the division of the region in Paser Regency. The method used is qualitative supported by NVivo 12 Plus software through coding data on online news sites. The results of the study stated that the local political elit had a role in the process of regional expansion, starting from the Regent to members of the Indonesian Parliament. The dominance of political interests became more apparent when the issue of pemekaran began to emerge, starting from DOB Paser Tengah and $D O B$ Paser Selatan. Both of them proposed the division. As administrative regions of expansion, Batu Sopang and Muara Komam sub-districts have a strategic position because they have abundant natural resources, especially coal mines, as well as plantation and mining products. Initially the two sub-districts chose to join the Central Paser DOB, but due to the dominance of the local elit in playing political strategy, the two sub-districts separated from Central Paser and merged into the South Paser DOB. Based on this fact, South Paser succeeded in getting the division recommendations. Until now the South Paser division process has reached the Prolegnas stage. But it was temporarily stopped due to the Moratorium policy from the Central Government.

Keywords: Regional Expansion; Local Elit; Natural Resources

\section{PENDAHULUAN}

Keterbukaan politik yang terjadi sejak 1998 membuka peluang besar perubahan tatanan kenegaraan yang lebih demokratis (Zuhro, 2018:1). Keterbukaan tersebut salah satunya adalah adanya kebijakan politik. Kebijakan politik akan berdampak pada penerimaan atau penolakan masyarakat atas apa yang dilakukan pemerintah (Qodir, 2019:139). Salah satu bentuk kebijakan politik tersebut adalag bergantinya pemerintahan yang sentralistik menjadi desentralistik, contohnya adalah otonomi daerah. Otonomi daerah yang bersandar pada UU Nomor 22 Tahun 1999, yang selanjutnya direvisi menjadi UU Nomor 32 Tahun 2004 tentang Pemerintahan Daerah (Rifdan, 2010:23; Wibisono, 2017:6435; Audia, 2015:2; Rohmah, 2018:91) dan yang selanjutnya diubah kembali menjadi UU Nomor 23 Tahun 2014.

Salah satu aktualisasi dari kebijakan Desentralisasi dan Otonomi Daerah yang timbul dalam keanekaragaman di Indonesia adalah: Pemekaran wilayah yaitu pembentukan wilayah administratif baru di tingkat provinsi maupun kota (Kurniawan, 2015:2) dan kabupaten/kota (Brata, 2008:1). Hal tersebut menjadikan pemekaran menjadi konsekuensi logis dari kebijakan desentralisasi politik (Yusoff, 2010). Salah satu cara yang dapat dilakukan untuk mempercepat pembangunan ialah dengan melakukan pemekaran wilayah agar masyarakat mendapatkan pelayanan dan mempercepat pembangunan (Audia, 2015:3).

Di seluruh Indonesia, retorika kampanye selalu menyebut-nyebut tiga alasan utama untuk menciptakan kabupaten baru: bahwa hal itu akan semakin mendekatkan pemerintah dengan rakyat, bahwa akan menguntungkan kemakmuran ekonomis, dan bahwa adalah kehendak rakyat untuk memiliki kabupaten mereka sendiri (Vel, 2007). Senada dengan pernyataan tersebut, usulan pemekaran wilayah juga banyak merepresentasikan kepentingan elit lokal dengan motif sejarah, etnik dan ekonomi (Rohmah, 2018). Berdasarkan penelitian yang dilakukan Rohmah menyatakan bahwa Pemerintah Daerah Jawa 
Barat tidak merekomendasikan pemekaran Provinsi Banten karena khawatir akan kehilangan PAD dan DAU (Lubis, 2000). Hal tersebut merupakan salah satu contoh kecil yang membenarkan bahwa memang sumber daya alam memiliki kedudukan yang siginifkan.

Wacana mengenai pemekaran wilayah itu berkembang dan menjadi fokus pembicaraan di berbagai kalangan (Asosiasi Antropologi Indonesia (AAI), 2011; Brata, 2008; Chauvel, 2005; Hommers, 2003; Suryawan, 2013). Para elit lokal membicarakan masalah pemekaran wilayah dengan sudut pandang kepentingan para elit (Suryawan, 2018:1). Individu yang memiliki otonomi dan bertindak secara rasionalitas yang dimiliki disebut dengan aktor (Trijono, 2011:100). Aktor selalu memiliki peran dalam proses pelaksana kegiatan dari mulai proses pengajuan pemekaran hingga proses pengesahan (Afzalurrahman, 2016:3). Elit-elit lokal tersebut memiliki peran masing-masing dalam proses pemekaran.

Pemekaran daerah yang berkembang saat reformasi berawal dari kelompok masyarakat maupun aspirasi dari sebagian elit politik. Terdapat kecenderungan ketika pembentukan daerah otonomi baru atau pemekaran tak jarang selalu diawali dengan elit lokal, selanjutnya adanya pengumpulan masa untuk meminta dukungan atau persetujuan, sebelum akhirnya menyampaikan proposal pemekaran kepada pihak berwenang, seperti DPRD, DPR RI sampai pada Kemendagri (Rohmah, 2018:92).

Pemekaran wilayah merupakan salah satu proses sosial politik yang sangat kompleks. Karena segala bentuk problematika dan dinamika yang terjadi seputar pemekaran merupakan sebuah refleksi penyelenggaraan otonomi daerah. Pemekaran wilayah sejatinya selain dimaksudkan untuk mendekatkan pelayanan kepada masyarakat, pemekaran wilayah juga dapat menjadi tempat bagi aktor politik untuk mencapai tujuannya, salah satunya seperti memperoleh kekuasaan dalam politik. Kekuasaan yang didapat tersebut dibagi pada kekuasaan politik tingkat lokal, hal tersebut merupakan sebuah masalah krusial yang selama ini kurang teramati (Tirtosudarmo, 2008).

Terdapat tiga faktor yang dapat mempengaruhi pemekaran wilayah, di antaranya ialah faktor ekonomi, politik dan sosial budaya (Suseno, 2008:57). Faktor ekonomi yakni keinginan dari daerah untuk mengatur sumber daya alam daerahnya seutuhnya. Selain itu faktor ekonomi juga memberikan tambahan sumberdaya fiskal. Faktor politik, yakni pengusulan pembentukan DOB lebih dominan mengarah pada lobi politik, hal tersebut nampak dari anggota DPR yang sangat bersemangat mengusulkan usulan pemekaran daerah tentunya dengan biaya yang tidak sedikit, karena mereka membutuhkan banyak uang untuk kampanye, baik partai politik maupun kampanye mereka sendiri. Faktor sosial kebudayaan, yaitu bahwa masyarakat memiliki kecenderungan untuk memilih tinggal di daerah yang lebih memiliki kesamaan, baik bahasa, agama, karakter kota-desa, tingkat pendapatan, atau etnis.

Faktor ekonomi yang berkaitan dengan potensi daerah memiliki makna bahwa setiap daerah yang dimekarkan harus memiliki potensi sumber daya alam yang dapat dijadikan sebagai PAD. Namun seiring berjalannya waktu, politik sumber daya alam banyak menuai kontroversi karena berkaitan dengan politik lingkungan seperti mengeksploitasi hutan, baik dalam sektor pertambangan atau illegal-loging. Faktor-faktor tersebut memiliki kedudukan yang krusial dalam proses pemekaran. Sehingga dapat dikaji lebih dalam apa motif pemekaran suatu daerah atau wilayah. Hal tersebut sejalan dengan pemekaran wilayah yang terjadi di salah satu kabupaten di Provinsi Kalimantan Timur, tepatnya di Kabupaten Paser (Tribunnews, 2019).

Berdasarkan pengamatan awal penulis, faktor ekonomi dan politik menjadi salah satu pemicu pemekaran wilayah di Kabupaten Paser. Faktor politik menjadikan elit politik lokal memiliki panggung dalam ranah pemekaran wilayah, sedangkan faktor ekonomi menjadi jembatan penghubung dan aspirasi yang disuarakan mengingat sumber daya alam menjadi salah satu syarat dalam pemekaran. Hal tersebut sesuai dengan data bahwa Kabupaten Paser merupakan daerah penghasil tambang batu bara di Kalimantan Timur. Tabel 1. merupakan rekapitulasi Tambang batu bara di Kalimantan Timur.

Tabel 1. Kabupaten Penghasil Tambang di Kalimanatan Timur

\begin{tabular}{|c|c|c|c|c|c|}
\hline \multirow[t]{2}{*}{ Kabupaten/Kota } & $\begin{array}{c}\text { Pertambangan dan } \\
\text { Penggalian }\end{array}$ & $\begin{array}{c}\text { Pertanian, Kehutanan } \\
\text { dan Perikanan }\end{array}$ & $\begin{array}{c}\text { Industri } \\
\text { Pengelolaan }\end{array}$ & Konstruksi & \multirow{2}{*}{$\begin{array}{c}\text { Wilayah Batu } \\
\text { Bara (\%) }\end{array}$} \\
\hline & \multicolumn{4}{|c|}{ Presentase Kontribusi Sektor Usaha ADHK (\%) } & \\
\hline Penajam Paser Utara & 34 & 21 & 16 & 9 & 68 \\
\hline Kutai Barat & 55 & 13 & 5 & 10 & 62 \\
\hline Samarinda & 15 & 2 & 8 & 19 & 34 \\
\hline Kutai Timur & 84 & 6 & 3 & 2 & 33 \\
\hline Kutai Kartanegara & 74 & 9 & 3 & 6 & 24 \\
\hline Paser & 74 & 12 & 4 & 2 & 13 \\
\hline Berau & 64 & 9 & 4 & 4 & 13 \\
\hline
\end{tabular}

Sumber: Data PRDB tahun 2016 (Badan Pusat Statistik, BPS \& Ectractive Industries Transparency Initiative, EITI diolah) 
Data di atas dapat diketahui bahwa Kabupaten Paser memiliki potensi kekayaan sumber daya alam di bidang pertambangan dengan urutan ke 2 terbesar di Kalimantan Timur. Kekayaan sumber daya alam yang melimpah tersebut yang membuat Kabupaten Paser ingin kembali memekarkan wilayahnya. Pada tahun 2002 Kabupaten Paser telah berhasil memekarkan wilayahnya yakni Kabupaten Penajam Paser Utara (PPU) yang saat ini menjadi lokasi Ibu Kota Negara Indonesia.

Berkaca dari hal tersebut, selain memiliki kesiapan politik dan sosio kultural, modal ekonomi dengan memiliki potensi sumber daya alam yang melimpah juga menjadi salah satu faktor pendukung untuk melakukan pemekaran wilayah. Terlebih pada sektor pertambangan. Dalam lingkup Kabupaten Paser sendiri, berikut merupakan data tambang batu bara yang diproduksi.

Tabel 2. Produksi Batubara Kabupaten Paser 2013-2017

\begin{tabular}{cc}
\hline $\begin{array}{c}\text { Tahun } \\
\text { Year }\end{array}$ & $\begin{array}{c}\text { Produksi } \\
\text { Production (Ton) }\end{array}$ \\
\hline$(1)$ & $(3)$ \\
2013 & 39532235 \\
2014 & 41618636 \\
2015 & 39694250 \\
2016 & 32687753 \\
2017 & 32879307 \\
\hline
\end{tabular}

Sumber: Dinas Energi dan Sumber Daya Mineral Provinsi Kalimantan Timur

Adanya kekayaan sumber daya alam tambang batu bara tersebut yang akhirnya menuai polemik pemekaran wilayah di Kabupaten Paser. Hal tersebut menjadi isu yang kian memanas ketika di Kabupaten Paser terdapat dua isu pemekaran wilayah, yakni pemekaran Paser Tengah dan Paser Selatan (Antaranews, 2012). Pada tahun 2008, usulan pemekaran Paser Tengah mulai muncul ke permukaan dengan menggandeng lima kecamatan sebagai syarat administratif pemekaran, di antaranya adalah Kecamatan Long Kali, Long Ikis, Kuaro, Batu Sopang dan Muara Komam.

Namun pada tahun 2012, kembali muncul ide pemekaran yakni DOB Paser Selatan yang terdiri dari Kecamatan Batu Engau, Tanjung Harapan, Muara Samu, Batu Sopang dan Muara Komam. Terdapat kejanggalan karena kedua DOB memiliki dua kecamatan yang sama sebagai bagian dari daerah pemekaran, kecamatan tersebut ialah Batu Sopang dan Muara Komam. Keduanya menjadi kecamatan yang diperebutkan. Setelah ditelisik lebih jauh, maka faktor yang menjadi alasan terkuatnya ialah karena kedua kecamatan merupakan kecamatan potensial yang memiliki sumber daya alam melimpah yakni sebagai penghasil tambang batu bara terbesar di Kabupaten Paser yang terletak di Batu Sopang dan Muara Komam yang dikenal sebagai sentra bawang merah di Kabupaten Paser bahkan di Kalimantan Timur.

Studi terdahulu seperti yang diteliti bahwa pemekaran wilayah merupakan salah satu proses sosial politik yang sangat kompleks. Selain dimaksudkan untuk mendekatkan pelayanan kepada masyarakat, pemekaran wilayah nyatanya dapat menjadi tempat bagi aktor politik untuk mencapai tujuannya, salah satunya seperti mendapatkan kekuasaan politik (Tirtosudarmno, 2008). Wacana pemekaran selalu menjadi hal yang menarik untuk dibahas, karena segala bentuk problematika dan dinamika yang terjadi seputar pemekaran merupakan salah satu refleksi penyelenggaraan otonomi daerah.

Potensi sumber daya alam yang dimiliki oleh Kecamatan Muara Komam dan Kecamatan Batu Sopang menjadi salah satu faktor dalam menopang penghasilan daerah dan berpotensi menjadikan daerah tersebut maju dan tidak tertinggal. Dengan adanya potensi alam tambang batu bara dan hasil pertanian dan perkebunan lainnya tentu hal tersebut akan memudahkan suatu daerah berkembang dan maju. Potensi daerah tersebut tentu sangat berguna dalam memberikan kontribusi dalam Pendapatan Asli Daerah (PAD).

Hal tersebut didukung oleh penelitian yang dilakukan oleh (Canaldhy et al., 2017:54) bahwa faktor sumber daya alam yang melimpah menjadi motif legitimasi dan menjadi keyakinan elit jika DOB dapat lebih maju dan berkembang setelah pemekaran, bahkan mengalahkan daerah induk.

Latar belakang di atas maka penulis tertarik untuk menganalisis tentang motif politik sumber daya alam dalam pemekaran sebagai penguat dalam pembentukan daerah otonomi baru (DOB). Dalam penlitian ini juga penulis ingin melihat bagaimana faktor ekonomi dan politik mendominasi kontestasi pemekaran wilayah di Kabupaten Paser. Politik sumber daya alam yang ingin dianalisis dalam tulisan ini adalah seberapa jauh actor memperjuangkan pemekaran dengan melihat potensi kekayaan alam yang ada di masing-masing kecamatan. Elit politik lokal yang dimaksud adalah seseorang atau sekelompok oarng yang memiliki kekuasaan di daerah dan ikut menyuarakan isu pemekaran wilayah, seperti Bupati, Ketua Lembaga Adat Paser, dan anggota DPRD. Rumusan masalah yang digunakan dalam penelitian ini adalah "Bagaimana peran politik sumber daya alam terhadap kepentingan elit politik lokal dalam pemekaran wilayah di Kabupaten Paser Provinsi Kalimantan Timur?"

\section{METODE}

Penelitian ini bertujuan untuk mengeksplorasi lebih jauh tentang Politik Sumber Daya Alam: Studi 
Terhadap Kepentingan Elit Politik Lokal dalam Pemekaran Wilayah di Kabupaten Paser Provinsi Kalimantan Timur.

Jenis data dalam penelitian ini ialah kualitatif dengan memanfaatkan software NVivo 12 Plus. Penelitian kualitatif seperti yang dikemukakan oleh Creswell (2013:267-270) bahwa terdapat empat jenis strategi yang dapat digunakan untuk mengumpulkan data yakni observasi, wawancara, dokumendokumen, dan materi audio dan visual. Oleh karena itu, dalam penelitian ini penulis menggunakan studi pustaka atau pengumpulan dokumen. Studi pustaka atau kepustakaan merupakan serangkaian kegiatan berkaitan metode pengumpulan data secara pustaka, membaca dan mencatat serta mengolah bahan penelitian (Zed, 2003:3 Supriyadi, 2016:85), mengumpulkan informasi serta data dengan berbagai macam material pustaka, seperti dokumen, makalah, buku, majalah, penelitian terdahulu, kisah-kisah sejarah dan lainnya (Mirzaqon \& Purwoko, 2015). Data sekunder seperti jurnal dan berita online yang bereputasi juga turut dimanfaatkan guna mendapatkan data yang valid. Dalam hal mengolah data sekunder penulis memilah dan melakukan review dari berbagai sumber jurnal yang bereputasi.

Proses review jurnal dilakukan dengan metode systematic literature review dari junal nasional maupun internasional dalam kurun waktu 20102020. Kriteria jurnal yang direview berdasarkan kesamaan penelitian atau penelitian yang linier tentang politik sumber daya alam dan pemekaran wilayah. Kata kunci yang digunakan seperti political resources, regional expansion, and local elit.

Selanjutnya untuk media online, penulis menggunakan fitur NVIVO 12 Plus untuk mengolah data. NVivo merupakan Qualitative Data Analysis (QDA) menggunakan perangkat lunak yang diproduksi oleh QSR International yang memiliki banyak keunggulan dan dapat secara signifikan meningkatkan kualitas penelitian. Media online yang digunakan bersumber dari 3 berita online yakni (Antaranews, Kaltim Post, dan Tribun Kaltim). Masing-masing berita online tersebut di Ncapture sebanyak 5 berita dengan mengangkat tema yang sama yakni pemekaran daerah di Kabupaten Paser pada kurun waktu saat wacana pemekaran mencuat pada tahun 2012-2014. Dasar penentuannya berdasarkan isu yang sesuai dengan penelitian seperti tentang penentuan. Penentuan media online berdasarkan banyaknya pemberitaan yang dimuat dari isu tersebut pada media online.

Analisis data kualitatif menjadi lebih mudah dan menghasilkan hasil yang lebih profesional (AlYahmady \& Al Abri, 2013:182). Salah satu fitur yang digunakan yakni analisis Coding Similarity kemudian ditarik sebuah kesimpulan. Coding Similarity yakni membandingkan hasil coding antara satu file dan node, file atau node yang telah di coding dikelompokkan berdasarkan nilai yang tinggi dan nilai yang rendah, hasil dari nilai tersebut dapat ditampilkan dalam cluster. Namun sebelum dilakukan coding, penulis terlebih dahulu mengcapture berita online tersebut dan memasukkannya dalam NVIVO 12 Plus. Selanjutnya memasukkan indikator penelitian dan case (berita online). Selanjutnya dilakukan proses Coding Similarity dan dianalisis hingga data lengkap.

\section{HASIL DAN PEMBAHASAN}

\section{Analisis Kesiapan Pemekaran Wilayah di Kabupaten Paser}

Berdasarkan PP No. 78 Tahun 2007 tentang Tata Cara Pembentukan, Penghapusan, Dan Penggabungan Daerah, ada 3 syarat yang harus dipenuhi, yakni syarat administratif, syarat teknis, dan fisik kewilayahan. Melihat dari syarat administratif, Kabupaten Paser Selatan telah mendapatkan persetujuan dari DPRD Kabupaten/Kota, Bupati, DPRD Provinsi, Gubernur dan telah mendapat rekomendasi dari Menteri.

Untuk syarat teknis seperti faktor kemampuan ekonomi, potensi daerah, sosial budaya, sosial politik, kependudukan, luas daerah, pertahanan, keamanan, kemampuan keuangan, tingkat kesejahteraan masyarakat, dan rentang kendali penyelenggaraan pemerintahan daerah dirasa telah cukup mumpuni berdasarkan kajian akademik dan perhitungan yang dilakukan oleh tim kajian akademik Fisipol Universitas Gajah Mada terhadap seluruh indikator sebagaimana dipersyaratkan dalam PP 78 Tahun 2007, maka disimpulkan bahwa rencana pembentukan calon Daerah Otonom Baru Kabupaten Paser Selatan memenuhi syarat dan layak untuk dilakukan, adapun jumlah akumulasi nilai dari keseluruhan indikator tersebut menunjukan bahwa:

1. Calon DOB Kabupaten Paser Selatan memperoleh nilai sebesar : 428 dari total nilai 500 (dikatagorikan SANGAT MAMPU)

2. Calon Daerah Induk (DI) Kabupaten Paser memperoleh nilai sebesar 438 dari total nilai 500 (dikatagorikan SANGAT MAMPU) (Darmo, 2017).

Selain itu, kekayaan sumber daya alam yang dimiliki oleh Kabupaten Paser di antaranya ialah Sektor Pertambangan dan Penggalian. Sektor Pertambangan dan Penggalian merupakan sektor yang paling besar memberikan kontribusi terhadap pembentukan PDRB Kabupaten Paser. Besaran 
nilai kontribusi sektor pertambangan dan penggalian terhadap struktur perekonomian Kabupaten Paser adalah sebesar 71,31 persen. Sedangkan sektor lain yang juga memberikan nilai konstribusi cukup besar terhadap pembentukan perekonomian Kabupaten Paser adalah sektor pertanian, kehutanan, dan perikanan (12,56 persen) (LAKIP, 2017).

Perekonomian Kabupaten Paser yang didominasi oleh penggalian atau sektor pertambangan batu bara dengan kontribusi terhadap Produk Domestik Regional Bruto (PDRB) sebesar 71, 31 persen. Sedangkan untuk kontribusi di Kaltim, Paser menempati posisi keenam dengan angka 7,32 persen atau menyumbang Rp 37,191 triliun selama 2016. Pertumbuhan ekonomi berdasar lapangan usaha masih didominasi bisnis pertambangan. Pertambangan dan penggalian mencapai 71,31 persen, diikuti pertanian 12,56 persen, dan industri pengolahan 4,51 persen (http://humas.paserkab.go.id).

Hasil survei yang dilakukan Badan Pusat Statistik (BPS) Kabupaten Paser, ketergantungan Kabupaten Paser terhadap Sumber Daya Alam (SDA) yang tak terbarukan seperti tambang batu bara, Kabupaten Paser menjadi yang terendah pertumbuhan ekonominya selama tahun 2016. Kabupaten Paser minus 4,79 persen. Hal ini terjadi karena ketergantungan pada sektor pertambangan. Pada saat harga komoditas tersebut turun, berimbas secara keseluruhan.

Oleh sebab itu, Pemeritah Kabupaten Paser harus lebih jeli dalam melihat potensi SDA yang tersedia untuk dapat dimanfaatkan dan menambah PAD. Salah satunya ialah dengan memanfaatkan dan meningkatkan pada sektor pertanian dan perdagangan. Pertanian dan perdagangan tetap tumbuh dalam lima tahun terakhir, walaupun melambat dalam beberapa tahun tertentu. Berdasar struktur perekonomian, pertanian, dan industri pengolahan menjadi sektor pilihan yang layak untuk terus ditingkatkan dan dikembangkan. Selama lima tahun terakhir, perekonomian Paser tanpa batu bara masih tetap tumbuh, yakni sebesar 3,60 persen (http:/humas.paserkab.go.id).

Fenomena tersebut membuat Pemerintah Kabupaten Paser lebih teliti dalam mengeksploitasi potensi SDA. Salah satunya untuk tidak selalu bergantung pada sektor tambang dan mulai memanfaatkan sektor lain di luar tambang. Potensi sumber daya alam Kabupaten Paser di luar tambang meliputi padi, jagung, kedelai, bawang merah, kelapa sawit, karet dan masih banyak lagi. Selanjutnya Kabupaten Paser juga memiliki hasil perikanan tangkap dan perikanan budidaya serta sektor peternakan meliputi daging dan telur. Potensi tersebut yang harus dimanfaatkan dan dimaksimalkan untuk dapat mengentaskan diri dari ketergantungan pada sektor tambang, karena pertambangan tidak selamanya beroperasi dan mengekspoitasi SDA di Kabupaten Paser. Data di atas dapat disimpulkan sebagai berikut:

Tabel 3. Potensi Sumber Daya Alam Kabupaten Paser

\begin{tabular}{llc}
\hline $\begin{array}{c}\text { Jenis Potensi } \\
\text { Sumber Daya }\end{array}$ & Jenis Produksi & $\begin{array}{c}\text { Capaian (dalam \%) } \\
\text { tahun 2017 }\end{array}$ \\
\hline \multirow{2}{*}{ Pertanian } & Padi & 86 \\
& Jagung & 330 \\
& Kedelai & 27 \\
& Perikanan & 100,6 \\
Perikanan & Tangkap & 82 \\
& Perikanan & 67 \\
Perkebunan & Kudidaya & 101 \\
& Kelapa Sawit & 57 \\
Peternakan & Daging & 57 \\
\hline & Telur & Sumber: LAKIP Kabupaten Paser, 2017
\end{tabular}

Selanjutnya ialah syarat fisik kewilayahan, dimana DOB Kabupaten Paser Selatan telah memenuhi syarat tersebut yang meliputi Kecamatan Batu Engau, Tanjung Harapan, Muara Samu, Batu Sopang dan Muara Komam.

Berdasarkan hal tersebut, jelas terlihat bahwasannya Kabupaten Paser dinilai sudah cukup syarat untuk melakukan pemekaran. Hal tersebut juga didukung oleh penelitian yang dilakukan oleh (Darmo, 2017:362; Simamora \& Halim, 2012:49) yang menyatakan bahwa persyaratan yang harus dimiliki oleh daerah otonom baru di antaranya adalah kemampuan ekonomi dan potensi daerah. Potensi sumber daya alam tersebut dapat dimanfaatkan oleh daerah untuk meningkatkan dan menambah PAD.

Persyarataan tersebut dinilai berdasarkan hasil kajian daerah terhadap indikator-indikator kesiapan teknis. Namun faktor lain juga sangat penting dan tidak boleh diabaikan begitu saja. Namun, hasil kajian akademik dari Universitas Gadjah Mada sudah cukup meyakinkan jika DOB Paser Selatan layak untuk dimekarkan.

\section{Kronologis dan Urgensi Pemekaran Wilayah di Kabupaten Paser}

Pemekaran wilayah dinilai menjadi salah satu cara untuk mewujudkan sistem pemerintahan yang lebih baik (Simamora \& Halim, 2012:48) meski kerap kali menimbulkan banyak permasalahan. Beberapa permasalahan yang muncul di antaranya ialah perebutan aset daerah.

Kebijakan dan sikap pemerintah dalam pembangunan menjadi sumber penyebab kerusakan dan pencemaransumberdayaalam(Syafa'at, 2011:85). Salah satu bentuk sikap tersebut dapat dilihat dari pemekaran daerah. Daerah yang kaya dieksploitasi sumber daya 
alamnya guna mendongkrak perekonomian daerah namun kerap kali menimbulkan masalah baru seperti kerusakan alam akibat eksploitasi yang kerap kali menyisakan kubangan bekas galian tambang tanpa tindakan penghijauan.

Provinsi Kalimantan Timur merupakan salah satu provinsi yang kaya akan sumber daya alamnya, termasuk tambang batu bara. Isu pemekaran kemudian mencuat di salah satu kabupaten yang berbatasan langsung dengan Provinsi Kalimantan Selatan, Kabupaten yang dimaksud ialah Kabupaten Paser. Sebelumnya, Kabupaten Paser telah berhasil melakukan pemekaran. Kabupaten Penajam Paser Utara merupakan wilayah hasil pemekaran dari Kabupaten Paser sejak tahun 2002 (Tribunnews, 2019).

Keberhasilan dalam memekarkan wilayah tersebut menjadi salah satu faktor yang mendorong untuk kembali memekarkan wilayah di Kabupaten Paser. Namun di Kabupaten Paser terdapat isu yang memanas yakni munculnya dua wacana pemekaran daerah, yakni Kabupaten Paser Tengah dan Kabupaten Paser Selatan (Antaranews, 2012). Wacana pembentukan Kabupaten Paser Tengah sudah muncul sejak tahun 2006 (Tribunnews, 2012) sedangkan menurut sumber dari (Antaranews, 2012) menyatakan bahwa wacana Paser Tengah mulai muncul tahun 2008, bahkan pada saat itu isu pemekarannya sudah diparipurnakan oleh DPRD Paser. Kabupaten Paser Tengah yang akan dibentuk terdiri dari Kecamatan Batu Sopang, Kecamatan Muara Komam, Kecamatan Kuaro, Kecamatan Long Ikis, dan Kecamatan Long Kali.

Wacana pembentukan Paser Tengah sejatinya lebih dahulu muncul dan lebih dahulu diparipurnakan oleh DPRD, selanjutnya wacana pembentukan Paser Selatan mulai mencuat kisaran tahun 2012 saat Bupati Paser Ridwan Suwidi memberikan sambutan pada HUT Kideco Jaya Agung (salah satu perusahaan tambang terbesar di Kalimantan Timur) mendukung wacana pemekaran Paser Selatan. Hal tersebut yang membuat politisi PKS (Aksa Arsyad) mulai menanggapi serius (Antaranews, 2012) serta mulai melakukan upaya untuk memperjuangkan pemekaran Paser Selatan.

Pada 1 Oktober 2013, ratusan massa pendukung pemekaran Daerah Otonom Baru (DOB) Paser Selatan memadati gedung DPR dan menuntut dewan agar menggelar paripurna untuk menyetujui usulan pembentukan Kabupaten Paser Selatan (Antaranews, 2013). Berdasarkan hasil Rapat Dengar Pendapat (RDP) yang dilakukan oleh DPRD Paser pada 2 Oktober 2013 menyatakan bahwa DPRD Paser hanya merekomendasikan pembentukan Daerah Otonomi Baru Paser Tengah (Pasteng) (Antaranews, 2013).
Namun fenomena berbeda terjadi pada 21 November 2013. Sidang paripurna kembali digelar. Berdasarkan sidang paripurna yang dilakukan oleh anggota DPRD Paser akhirnya merekomendasikan pembentukan DOB Paser Selatan. Persetujuan itu ditindaklanjuti dan diperkuat dengan adanya surat Gubernur Kaltim tertanggal 10 Desember 2013, surat dari Bupati Kabupaten Paser pada 30 Agusutus 2013, dan beberapa surat dari DPRD Kabupaten Paser terkait persetujuan pembentukan DOB Kabupaten Paser Selatan, serta surat dari Komisi I DPRD Kaltim Nomor 012/Komisi///II/2014 tertanggal 14 Februari 2014 perihal Mohon Persetujuan Pemekaran DOB Paser Selatan (Kaltim Post, 2014).

Pemberlakuan rekomendasi Paser Selatan membuat rekomendasi terhadap Paser Tengah dicabut. Hal tersebut berdasarkan sidang paripurna DPRD yang menghasilkan keputusan untuk mencabut Surat Keputusan DPRD Paser nomor 11 sampai dengan nomor 17 tahun 2009 tentang Persetujuan Pembentukan Daerah Otonom Baru Paser Tengah, hal tersebut karena Paser Tengah dinilai tidak mencukupi persyaratan untuk dapat dimekarkan menjadi DOB sesuai dengan PP No. 78 tahun 2007 pasal 6. Selanjutnya pembentukan DOB Kabupaten Paser Tengah agar dapat ditinjau dan ditata kembali, sembari menunggu pemekaran kecamatan lain di Kabupaten Paser (Antaranews, 2013; Kaltim Post, 2013). Padahal faktanya, DOB Paser Tengah telah melakukan studi kelayakan oleh tim dari Universitas Mulawarman pada tahun 2012, dan dinyatakan layak mekar dengan memperoleh poin 385 .

Oleh sebab itu, Paser Selatan otomatis melaju menjadi daerah yang direkomendasikan untuk dimekarkan. Selain itu, fenomena lainnya yang juga menjadi polemik yakni adanya perebutan 2 Kecamatan di Kabupaten Paser yakni Kecamatan Batu Sopang dan Kecamatan Muara Komam. Pada awalnya kedua Kecamatan tersebut masuk sebagai wilayah pemekaran Paser Tengah. Namun karena terdapat isu pemekaran wilayah Paser Selatan, maka kedua kecamatan tersebut memilih untuk keluar dan bergabung menjadi bagian dari DOB Paser Selatan mengingat wilayahnya memasuki zona bagian selatan dan Batu Sopang yang direkomendasikan untuk menjadi Ibu Kota Kabupaten Paser Selatan. Pada tahun 2014 sekretariat Tim Sukses Paser Selatan mulai dibangun dan relawan mulai digalakkan.

Selain itu, hal lain yang menjadi alasan yakni dikarenakan Bupati melihat berbagai pertimbangan, jika Paser Tengah melakukan pemekaran dengan formasi Kecamatan Batu Sopang, Kecamatan Muara Komam, Kecamatan Kuaro, Kecamatan Long Kali dan Kecamatan Long Ikis, maka kecamatan lain yang tidak masuk pemekaran akan menjadi bagian 
dari Kabupaten Induk, hal tersebut berpengaruh pada keberlanjutan Kabupaten Induk karena kecamatan yang bergabung ialah kecamatan yang relatif tertinggal (Kaltimprocal.co, 2013) seperti Kecamatan Batu Engau, Tanjung Harapan dan Muara Samu. Dikatakan tertinggal dengan alasan letaknya yang sangat jauh dari pusat pemerintahan dan sulit untuk mendapatkan akses pelayanan, meskipun kecamatan tersebut memiliki sumber daya alam yang melimpah. Namun karena letaknya yang lebih pedalaman, membuat beberapa kecamatan dikatakan relatif tertinggal karena serba terbatas, baik itu listrik, jaringan internet, jalan, PDAM dan lain-lain.

Adanya motif politik dalam pemekaran menjadi hal yang sulit untuk dihindarkan. Baik dalam pemekaran Paser Tengah dan Paser Selatan maupun pada kejadian pemisahan dua kecamatan dari wilayah Paser Tengah ke Paser Selatan. Aktor atau elit lokal memiliki peran dalam mencapai tujuan dan kepentingan di balik pemekaran wilayah. Salah satunya ialah karena potensi sumber daya alam yang dimiliki oleh dua kecamatan tersebut dan dinilai lebih menjanjikan. Karena hampir semua kecamatan yang masuk dalam wilayah Paser Selatan memiliki potensi alam di bidang pertambangan. Sebagai contoh Batu Sopang yang merupakan kecamatan sentral penghasil tambang batu bara terbesar di Kabupaten Paser, Muara Komam dan Muara Samu juga memiliki potensi alam yang sama, bahkan Muara Komam juga memiliki keunggulan di bidang tanam pangan hortikultura Bawang Merah. Kecamatan Muara Komam dikenal sebagai sentra penghasil bawang merah di Kabupaten Paser, bahkan di Provinsi Kalimantan Timur (kaltim.litbang.pertanian.go.id) serta hasil jualnya menembus 3 Provinsi sekaligus, yakni Kaltim, Kalsel dan Kalteng.

Hasil tersebut lebih menguatkan untuk merealisasikan Pemekaran Kabupaten Paser Selatan yang memiliki nilai jauh lebih tinggi dari Paser Tengah. Oleh karena itu, Bupati Paser dan DPRD Paser mantap memberikan rekomendasi pemekaran Paser Selatan, dan hal tersebut juga mendapatkan persetujuan dari Gubernur Kalimantan Timur pada saat itu yakni Awang Faroek Ishak. Proses pembahasan lebih lanjut pemekaran tersebut sampai saat ini masih mandeg diakarenakan moratorium sejak tahun 2009 sampai pada pemerintahan Presiden Jokowi pada tahun 2014 hingga sekarang, moratorium Pemekaran Daerah masih belum dicabut. Hingga saat ini, Pemekaran Paser Selatan telah masuk dalam Program Legislasi Nasional (Prolegnas) di Kemendagri dan nama Paser Selatan tercatat dari 65 daerah usulan pemekaran di seluruh Indonesia.

Politik sumber daya alam menjadi kajian menarik dalam pemekaran wilayah. Kekayaan sumber daya alam masuk dalam ranah potensi daerah. Karena tidak mungkin suatu daerah yang akan dimekarkan tidak memiliki sumber daya alam yang dapat dijadikan sebagai penopang perekonomian. Kekayaan sumber daya yang ada memiliki implikasi teoritis yang jelas di tingkat daerah. Sumber daya alam mempengaruhi pertumbuhan ekonomi, dan ekonomi merupakan penentu penting kepercayaan politik (Sachs dan Warner, 2001; Espinal et al., 2006). Mekanisme yang mempengaruhi pertumbuhan ekonomi harus mengarah pada variasi dalam pembangunan ekonomi secara subnasional. Mereka yang berada di dekat proyek ekstraksi harus diuntungkan dari peningkatan pembangunan, infrastruktur, dan modal yang mengalir ke daerahdaerah ini. Konsekuensi ekonomi positif ini yang berasal dari pertambangan harus meningkatkan kepercayaan pada kepemimpinan politik. Sebaliknya, wilayah yang tidak dipengaruhi oleh ekstraksi seharusnya kurang menunjukkan kepercayaan terhadap kepemimpinan (Miller, 2015).

Adanya kekayaan sumber daya alam tambang batu bara tersebut yang akhirnya menuai polemik pemekaran wilayah. Urgensi pemekaran tersebut menuai polemik di dua Kecamatan yang menjadi rebutan antara Paser Tengah dan Paser Selatan. Kedua Kecamatan tersebut memiliki sumber daya alam tambang batu bara sehingga diperebutkan guna memenuhi salah satu syarat yakni potensi daerah yang dapat menunjang PAD. Dalam UndangUndang Dasar Negara Republik Indonesia tahun 1945 Pasal 33 ayat 3 menyatakan bahwa "Bumi, air dan kekayaan alam yang terkandung di dalamnya dikuasai oleh Negara dan dipergunakan untuk sebesar-besarnya kemakmuran rakyat".

Pasal tersebut dengan jelas mengatur kekayaan alam yang terkandung di bumi Indonesia. Dalam dinamika pemekaran yang terjadi di Kabupaten Paser, politik sumber daya alam menjadi isu yang sangat hangat diperbincangkan. Salah satu poin yang penting ialah potensi daerah. Dan salah satunya ialah perebutan sumber daya alam batu bara yang dimiliki dua Kecamatan berbeda di dua daerah pemekaran, yaitu DOB Paser Tengah dan Paser Selatan. Kedua wilayah tersebut memperebutkan dua Kecamatan penghasil Batu Bara terbesar di Kabupaten Paser.

\section{Faktor yang Mempengaruhi Pemekaran Wilayah}

Pembentukan daerah otonomi baru (DOB) merupakan salah satu cara untuk mendekatkan pelayanan kepada masyarakat. Kesenjangan yang banyak dialami oleh daerah-daerah di sebagian wilayah Kalimantan Timur sangat membutuhkan pemekaran sebagai salah satu cara agar pelayanan dapat dirasakan hingga seluruh lapisan masyarakat. 
Kondisi geografis yang luas membuat Kalimantan Timur memiliki kendala di bagian pelayanan. Terlebih di Kabupaten Paser. Kabupaten Paser merupakan kabupaten yang berbatasan langsung dengan Provinsi Kalimantan Selatan, hal tersebut membuat ketimpangan pembangunan sangat dirasakan oleh sebagian masyarakat yang tinggal di wilayah perbatasan, seperti Kecamatan Muara Komam. Jarak sejauh $86 \mathrm{Km}$ harus ditempuh jika masyarakat Kecamatan Muara Komam ingin melakukan pelayanan di Kabupaten Paser. Hal ini tentu saja berpengaruh terhadap efektivitas dan efisiensi waktu. Belum lagi jika terdapat kendala atau masalah lainnya.

Hal tersebut yang melatarbelakangi masyarakat untuk menyuarakan aspirasi untuk memekarkan wilayah di Kabupaten Paser. Pada dasarnya ide awal pemekaran selain untuk mendekatkan pelayanan kepada masyarakat yakni untuk mensejahterakan masyarakat. Kesejahteraan masyarakat tidak hanya soal kondisi ekonomi, pelayanan dan pengelolaan aset daerah, namun kepada pemerataan pelayanan dan tidak ada ketimpangan apalagi diskriminasi antar daerah. Apalagi jika ditelaah lebih ajuh, Kabupaten Paser memiliki kecamatan penghasil tambang batu bara, seperti Kecamatan Batu Sopang, Kecamatan Muara Komam, Kecamatan Muara Samu dan yang lainnya. Hal tersebut jika dimanfaatkan secara baik maka akan membawa kemaslahatan bagi masyarakat. Berikut merupakan coding (olah data) dari media online yang berkaitan dengan faktor yang mempengaruhi pemekaran wilayah. Hal tersebut dapat dilihat melalui item cluster sebagai berikut:

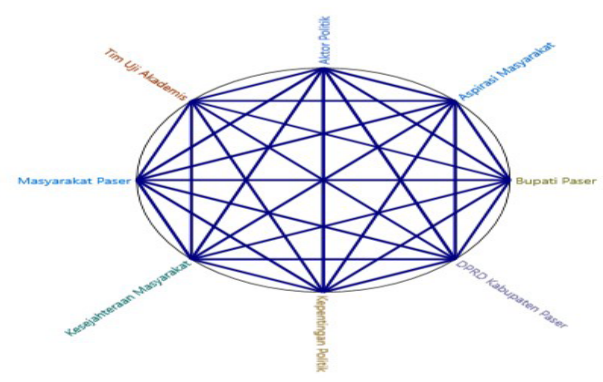

Gambar 1. Cluster analisis Pemekaran wilayah di Kabupaten Paser

Dari item cluster analisis di atas dapat dilihat bahwasannya masing-masing poin saling memiliki keterkaitan yang erat satu sama lain. Aktor Politik memiliki keterkaitan hubungan garis lurus terhadap Kepentingan Politik. Selanjutnya aktor politik juga memiliki kaitan dengan Aspirasi Masyarakat, hal tersebut membuktikan bahwa aktor politik bertindak sebagai penyalur aspirasi masyarakat yang ingin membawa perubahan dan meningkatkan kesejahteraan masyarakat. Dalam hal kesejahteraan masyarakat, pemekaran dinilai dapat memberikan harapan baru dalam mewujudkan kesejahteraan dan hal tersebut didukung oleh adanya potensi daerah yang dapat dimanfaatkan untuk menopang perekonomian Daerah Otonom Baru (DOB).

\section{a. Aktor Politik}

Pemekaran wilayah tentu tidak akan terlepas dari aktor politik atau elit politik yang memiliki peran yang dominan dalam proses pengajuan pemekaran. Tidak jarang, kepentingan politikjuga turut diselipkan guna mempermulus jalannya pemekaran wilayah. Aktor politik yang membawa misi masyarakat harus lebih dominan daripada kepentingan politik yang ada di belakangnya.

Dalam ranah keterlibatan aktor, hasil analisis Nvivo 12 Plus menyebutkan bahwa Keterlibatan Aktor memiliki presentase sebanyak 19,64\%. Hasil coding data dapat dilihat pada gambar berikut:

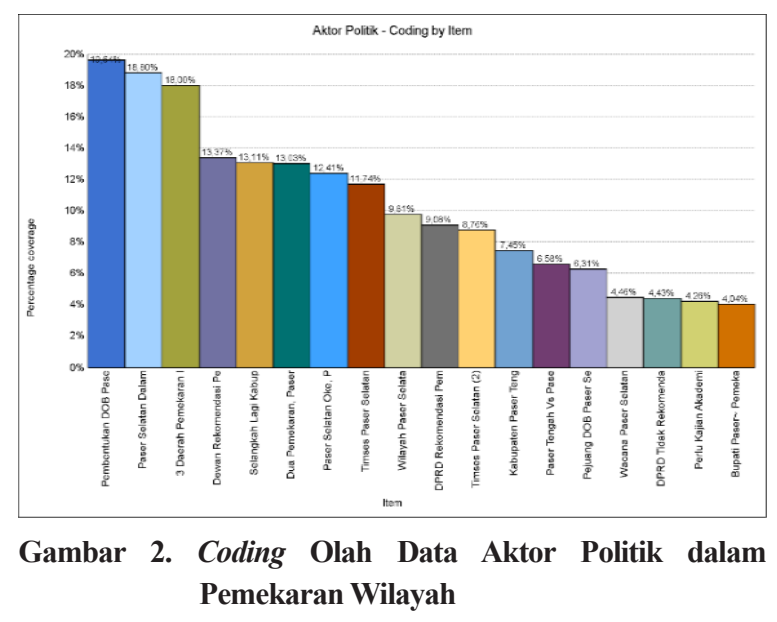

Hasil coding olah data dengan mengkategorisasikan berdasarkan indikator dan variabel penelitian maka diperoleh data tersebut. Frekuensi kata yang muncul selain aktor merupakan data pendukung ketika proses coding (olah data).

Pemekaran wilayah merupakan fenomena yang tidak akan terlepas dari keberadaan aktor politik atau elit politik sebagai penyambung lidah masyarakat dalam memeperjuangkan aspirasi masyarakat. Baik aktor yang lokal atau aktor nasional, mulai dari Gubernur, Bupati, Anggota DPRD, Tim Sukses, Lembaga Adat Paser (LAP), dan masyarakat biasa yang memiliki keterlibatan dalam proses pemekaran.

Aktor politik tersebut memiliki visi yang dibawa dalam proses pemekaran. Di Kabupaten Paser, beberapa aktor terlibat secara aktif dan masif diikuti oleh dukungan dari masyarakat Paser untuk melakukan pemekaran. Kepentingan politik menjadi hal yang tidak dapat dielakkan ketika terdapat wacana pemekaran dua wilayah dan perebutan dua kecamatan penghasil sumber daya alam. Elit lokal Kabupaten Paser yang memiliki andil dalam 
pemekaran Paser Selatan tentu memiliki segudang pertimbangan bahwa potensi alam menjadi hal yang patut untuk diperjuangkan mengingat berdasarkan informasi yang beredar bahwa perusahaan tambang batu bara lebih menyuport pemekaran Paser Selatan dan terdapat beberapa elit lokal yang ingin memiliki jabatan politis di daerah yang akan dimekarkan. Berikut merupakan tabel pemetaan elit politik lokal sampai nasional yang berperan dalam pemekaran di Kabupaten Paser, terutama yang memperjuangkan Paser Sekatan.

Tabel 4. Elit Lokal yang terlibat dalam pemekaran Paser Selatan

\begin{tabular}{|c|c|c|}
\hline Nama & Jabatan & Peran \\
\hline $\begin{array}{l}\text { H.M Ridwan } \\
\text { Suwidi }\end{array}$ & Bupati Paser & $\begin{array}{l}\text { Pencetus dan Pemberi } \\
\text { rekomendasi Pemekaran } \\
\text { Paser Selatan }\end{array}$ \\
\hline Arbain M. Noor & $\begin{array}{l}\text { Sekjen DOB } \\
\text { Paser Selatan } \\
\text { dan Ketua } \\
\text { Lembaga Adat } \\
\text { Paser }\end{array}$ & $\begin{array}{l}\text { Pelopor dan Tim Sukses } \\
\text { Pemekaran Paser Selatan }\end{array}$ \\
\hline Aksa Arsyad & $\begin{array}{l}\text { Anggota DPRD } \\
\text { Paser }\end{array}$ & $\begin{array}{l}\text { Menindaklanjuti isu } \\
\text { pemekaran Paser Selatan }\end{array}$ \\
\hline Ambo Lala & $\begin{array}{l}\text { Ketua Bappeda } \\
\text { Paser }\end{array}$ & $\begin{array}{l}\text { Menyetujui dan } \\
\text { Mendukung ide } \\
\text { pemekaran }\end{array}$ \\
\hline $\begin{array}{l}\text { Awang Faroek } \\
\text { Ishak }\end{array}$ & Gubernur Kaltim & $\begin{array}{l}\text { Menyetujui DOB Paser } \\
\text { Selatan }\end{array}$ \\
\hline Hetifah Sjaifudian & Anggota DPR RI & $\begin{array}{l}\text { Membawa aspirasi } \\
\text { pemekaran hingga } \\
\text { masuk Prolegnas }\end{array}$ \\
\hline
\end{tabular}

Sumber: Diolah Penulis dari berbagai sumber, 2020

Dari tabel di atas dapat diketahui bahwasanya elit politik lokal sampai nasional memiliki peran dalam proses pembentukan Daerah Otonom Baru Paser Selatan. Peran elit politik lokal dalam pemekaran memberikan dampak terhadap proses perkembangan. Meski salah satu faktornya ialah adanya kekayaan sumber daya alam, namun elit tersebut masih mengemban misi pemekaran sesuai dengan tujuan awal yakni mendekatkan pelayanan dan meningkatkan kesejahteraan meski terdapat kepentingan yang diselipkan. Paser Selatan sangat berpotensi untuk mekar dan siap secara teknis maupun administratif.

\section{b. Kepentingan Politik}

Dalam kegiatan politik tentu kepentingan politik menjadi hal yang patut untuk diperhitungkan. Awalnya, pemekaran daerah memiliki agenda yang baik dan memiliki dampak positif seperti demokratisasi yang semakin membaik, mendekatkan pelayanan publik, kemudahan untuk memelihara sarana dan prasarana, membuka lapangan kerja baru, serta motivasi dan inovasi membangun daerah. Namun dalam kenyataannya justru faktor politik terlihat sangat dominan dalam pemekaran daerah yang menjadikan ekspansi kebijakan regional di era reformasi menjadi gagal, karena tidak mampu menjawab pertanyaan kesejahteraan dan pelayanan masyarakat. Penyebab kegagalan ini adalah adanya kepentingan politik dari elit politik daerah dan DPRD (Santoso, 2012:1).

Kepentingan politik erat kaitannya dengan aktor politik yang memiliki jabatan politik dan dapat menggunakan kekuasaannya untuk melancarkan kepentingan yang dimiliki. Kepentingan politik dalam pemekaran seperti inginnya mendapatkan jabatan di daerah Otonomi Baru maupun hal-hal lain yang diinginkan oleh para aktor politik. Fenomena pemekaran provinsi, kabupaten dan kota yang hanya didasarkan pada kepentingan elit-elit politik tidak sejalan dengan jiwa atau semangat pemberian otonomi kepada daerah (Rifdan, 2010:24). Hasil coding data dapat dilihat pada gambar 3 sebagai berikut:

Gambar 3. Coding Data Kepentingan Politik dalam Pemekaran Wilayah

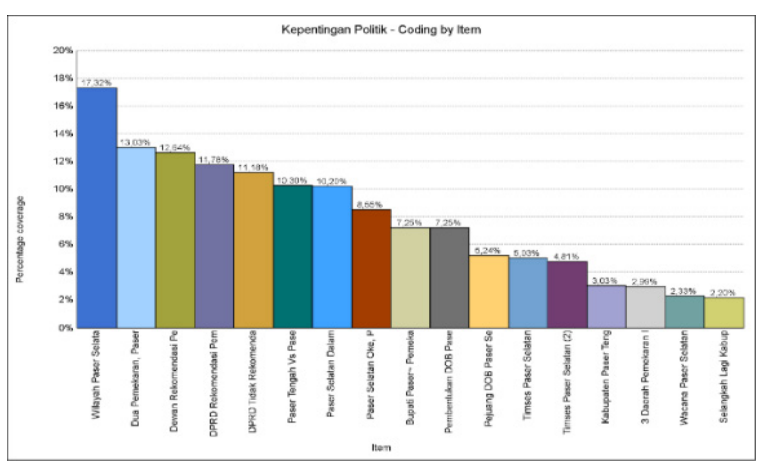

Hasil Coding datadenganmengkategorisasikan berdasarkan indikator dan variabel penelitian maka diperoleh data tersebut.

Kepentingan politik dalam pemekaran wilayah Kabupaten Paser Tengah atau Paser Selatan sudah pasti selalu ada. Kepentingan politik dapat berarti sebagai upaya untuk dapat memperjuangkan pemekaran hingga sampai tahap persetujuan oleh anggota DPRD atau Bupati. Kepentingan politik yang terlalu siginifan dapat membuat prinsip Otonomi daerah kehilangan arah. Dalam data di atas disebutkan bahwa kepentingan politik memiliki presentase sebesar $17,32 \%$. Hal ini menandakan bahwa dalam proses politik pemekaran wilayah di Kabupaten Paser, kepentingan politik menjadi salah satu faktor yang tidak dapat dilepaskan.

\section{Analisis: Disorientasi Pemekaran Wilayah di Kabupaten Paser berdasarkan Kepentingan Elit Lokal}

Aktor memerlukan sumber daya (resource) yang dijadikan sebagai modal untuk mendapatakan pengaruh di masyarakat (Haryanto, 2017). 
Sedangkan dalam desentralisasi, penerapan kebijakan desentralisasi melibatkan interaksi antar aktor utama, yakni pemerintah pusat (nasional), pemerintah daerah, dan masyarakat lokal.

Hampir dua dekade Republik Indonesia telah melaksanakan reformasi di segala aspek kehidupan bernegara; seiring dengan itu berlangsung pula ledakan tuntutan rakyat hingga di tingkat lokal yang menginginkan pendekatan pelayanan publik dan upaya kesejahteraan umum dapat diselenggarakan secara maksimal, efektif, dan efisien. Hal ini membutuhkan kesiapan dari elit-elit lokal yang demokratis dalam merespon tuntutan-tuntutan yang ada di daerahnya masing-masing, demikian pula dengan daerah (Zebua, 2017:2).

Kepentingan politik tentu menjadi hal yang patut untuk diperhitungkan. Awalnya, pemekaran daerah memiliki agenda yang baik dan memiliki dampak positif seperti demokratisasi yang semakin membaik, mendekatkan pelayanan publik, kemudahan untuk memelihara sarana dan prasarana, membuka lapangan kerja baru, serta motivasi dan inovasi membangun daerah. Namun dalam kenyataannya justru faktor politik terlihat sangat dominan dalam pemekaran daerah yang menjadikan ekspansi kebijakan regional di era reformasi menjadi gagal, karena tidak mampu menjawab pertanyaan kesejahteraan dan pelayanan masyarakat. Penyebab kegagalan ini adalah adanya kepentingan politik dari elit politik daerah dan DPRD (Santoso, 2012:1).

Amanat undang undang dasar Negara republik Indonesia yang secara jelas menyebutkan bahwa bumi, air, tanah beserta kekayaan didalamnya dikuasai oleh Negara dan dimanfaatkan sebesar besarnya untuk kemakmuran rakyat seakan hanya menjadi jargon. Namun menjadi tidak bermakna pada tataran operasionalnya (Mokoginta, 2009). Ketidakmampuan ini juga menimbulkan resistensi karena memang pada dasarnya mekanisme kontrol orde baru lebih represif dan menempatkan pengelolaan batu bara di bawah kendali pusat, di luar itu berarti kejahatan.

Era desentralisasi memberikan peluang bagi daerah untuk merespon pengelolaan sumber daya alam ini dalam kontrol pemerintah daerah. Lebih lanjut, kondisi ini diperparah oleh pragmatisme elit di tingkat lokal, pragmatisme elit diperburuk oleh perilaku elit politik yang memang lebih berorientasi kekuasaan ekonomi dan politik dibandingkan kemakmuran rakyat (Umarhadi, 2010:1). Pada dasarnya praktik monopoli dan penyerobotan asset Negara yang menguasai hajat hidup orang banyak dikuasai oleh sebagian sektor yang mengatas namakan rakyat namun sesungguhnya memperkaya koorporasi. Perilaku elit dan borjuasi lokal inilah yang melapangkan jalan bagi kepentingan dominasi asing.

Jika dilihat dari perspektif pemekaran yang ada di Kabupaten Paser, terutama dalam usulan DOB Paser Tengah dan Paser Selatan, terdapat aktor politik yang memainkan peran dengan sangat dominan. Di Paser Selatan misalnya, terdapat politisi partai PKS yakni Aksa Arsyad yang dengan keras menyuarakan pemekaran di Paser Selatan setelah Bupati Paser menyinggung isu pemekaran daerah otonomi baru Paser Selatan. PT Kideco Jaya Agung selaku tambang batu bara yang terbesar dan terletak di Keacamatan Batu Sopang tentu saja sangat mendukung perihal pemekaran daerah otonomi baru Paser Selatan dan bersiap memberikan akomodasi dan sumbangsih materi dalam rangka meluruskan pemekaran yang sudah digaungkan.

Akhirnya pemekaran Paser Selatan mulai mendapatkan titik terang dan persetujan, seolah melupakan Paser Tengah yang lebih dahulu berjuang. Hal tersebut sejalan dengan (Darmo, 2017:362) menyatakan bahwa persyaratan secara administrasi berdasarkan Peraturan Pemerintah Nomor 78 tahun 2007 telah terpenuhi dan dimiliki oleh calon Daerah Otonom Baru (DOB) Kabupaten Paser Selatan. Dimana Keputusan Bupati Paser keputusan Nomor: 135/KEP-145/2013 dikeluarkan pada tanggal 28 Februari 2013 tentang melajutkan proses pembentukan Daerah Otonom Baru (DOB) Kabupaten Paser Selatan, lalu dilanjukan dengan keputusan DPRD Kabupaten Paser Nomor 13 tahun 2013 tanggal 18 November 2013 yang turut memberikan persetujuan terhadap pembentukan Daerah Otonom Baru (DOB) Kabupaten Paser Selatan.

DPRD provinsi Kalimantan Timur mengeluarkan surat keputusan nomor 07 tahun 2014 tanggal 18 Februari 2014 tentang persetujuan terhadap Pembentukan CalonDaerah OtonomBaru Kabupaten Paser Selatan Provinsi Kalimantan Timur Sebagai pemekaran dari Kabupaten Paser, dalam kesepatan selanjutnya Gubernur Kalimantan Timur Pada tahun 2014 melalui Surat keputusan 135.1/K.132/2014 turut menyetujui pembentukan Daerah Otonom Baru (DOB) Kabupaten Paser Selatan, dimana proses selanjutnya diserahkan kepada pemerintah nasional sampai sekarang (Darmo, 2017:361).

Pemekaran Paser Tengah atau Paser Selatan keduanya merupakan aspirasi masyarakat yang diakomodir oleh elit politik. Namun dari ke dua daerah yang diusulkan mekar, urgensi pemekaran lebih condong kepada pemekaran Paser Selatan meski Paser Tengah lebih dahulu diparipurnakan dan berujung pembatalan. Hal tersebut karena dua Kecamatan yang menjadi rebutan karena potensi 
alam yang berlimpah memilih menggabungkan diri menjadi bagian dari Paser Selatan dari pada Paser Tengah. Dan hingga kini telah masuk dalam Prolegnas dan masih menunggu kebijakan pencabutan moratorium pemekaran daerah. Berikut merupakan alur proses pemekaran yang melibatkan para elit politik yang dalam proses pembentukan Daerah Otonomi Baru Kabupaten Paser Selatan.

Elit politik memiliki pengaruh yang besar dalam proses pembentukan DOB Paser Selatan. Terlepas dari faktor kepentingan politik dan adanya kekayaan sumber daya alam yang menjadikan Paser Selatan lebih mendapatkan banyak persetujuan dan lebih layak dimekarkan berdasarkan tim kajian studi dari Universitas Gadjah Mada dengan memperoleh skor sebanyak 425 dari 500 skor yang ditetapkan. Faktor sumber daya alam merupakan salah satu alasan krusial mengapa suatu daerah layak dimekarkan, hal tersebut karena setiap DOB harus memiliki potensi alam agar dapat memberikan pendapatan daerah. Hingga kini, usulan pembentukan DOB Paser Selatan telah masuk dalam Prolegnas. Namun terkendala pada kebijakan Moratorium dari Pemerintah Pusat.

\section{SIMPULAN}

Pemekaran wilayah Kabupaten Paser Selatan dinilai telah memenuhi syarat berdasarkan hasil kajian dari UGM. DOB Paser Selatan dirasa telah mampu untuk berpisah dari daerah induk karena telah cukup syarat administrasi, syarat teknis dan fisik kewilayahan. Dalam tulisan ini lebih menitikberatkan pada kekayaan potensi sumber daya alam yang menjadi alasan utama pemekaran wilayah di Kabupaten Paser. terlebih Kecamatan Batu Sopang dan Muara Komam merupakan 2 kecamatan yang memiliki kkekayaan SDA yang melimpah, mulai dari pertambangan hingga tanaman hortikultura bawang merah.

Meksi awalnya pemekaran sempat mengalami dualise, namun akhirnya DOB Paser Tengah yang berhasil mendapatkan persetujuan, hal ini didukung karena 2 kecamatan potensial memilih bergabung ke Paser Selatan. Keberhasilan pemekaran tentu tidak terlepas dari peran para elit lokal dalam memperjuangkan pemekaran. Selain itu faktor sumber daya alam merupakan salah satu alasan krusial mengapa suatu daerah layak dimekarkan, hal tersebut karena setiap DOB harus memiliki potensi alam agar dapat memberikan pendapatan daerah. Hingga kini, usulan pembentukan DOB Paser Selatan telah masuk dalam Prolegnas. Namun terkendala pada kebijakan Moratorium dari Pemerintah Pusat.

Studi di masa mendatang dapat dilakukan dengan melihat indikator apa saja selain aktor politik yang mendominasi dalam hal pemekaran daerah. Studi komparasi juga memungkinkan untuk dilakukan penelitian di masa depan.

\section{DAFTAR PUSTAKA}

Mokoginta, Lukman F. 2009. Bumi Bukan Milik Kapitalis, Pustaka Sinar Harapan, Jakarta.

Qodir, Zuly. 2019. Metodologi Politik Pemerintahan. Pustaka Pelajar : Yogyakarta

Satria, Arif. 2019. Politik Sumber Daya Alam. Yayasan Pustaka Obor Indonesia : Jakarta

Umarhadi, Yoseph, 2010. Jebakan Liberalisasi, Pragmatism, Dominasi Asing, Dan Ketergantungan Ekonomi Indonesia, Cakrawala Institute, Yogyakarta.

Vel, Jacqueline. 2005. Kampanye Pemekaran di Sumba Barat. Jakarta: Yayasan Obor Indonesia

Zed, Mestika 2003. Metode Penelitian Kepustakaan. Jakarta : Yayasan Obor Indonesia

UUD 1945 Pasal 33 ayat 3

UU Nomor 23 Tahun 2014 tentang Pemerintahan Daerah

Peraturan Pemerintah Nomor 78 tahun 2007 tentang Tata Cara Pembentukan, Penghapusan, dan Penggabungan Daerah

Data PRDB tahun 2016 (Badan Pusat Statistik, BPS \& Ectractive Industries Transparency Initiative, EITI diolah

Dinas Energi dan Sumber Daya Mineral Provinsi Kalimantan Timur

Afzalurrahman, M. 2016. Studi Politik Pemekaran : Dinamika Aktor Dalam Pembentukan Kecamatan Singkep Selatan Kabupaten Lingga Provinsi Kepulauan Riau Tahun 20112012. Jom Fisip, 3(2), 1-13.

Alyahmady, H. H., \& Al Abri, S. S. 2013. Using Nvivo For Data Analysis In Qualitative Research. International Interdisciplinary Journal Of Education, 2(2), 181-186. Https:// Doi.Org/10.12816/0002914

Audia, L. 2015. Analisis Politik Terhadap Usulan Pemekaran Desa Sidaraja Kecamatan Ciawigebang Kabupaten Kuningan.

Brata, A. G. 2008. Pemekaran Daerah Di Papua : Kesejahteraan Masyarakat Vs . Kepentingan Elit. 1-9.

Canaldhy, R. S., Wijaya, B. A., \& Hairi, M. I. A. 2017. Pemekaran Kabupaten Musi Rawas Utara Di 
Provinsi Sumatera Selatan Tahun 2013-2016. Jurnal Pemerintahan Dan Politik, 2(1), 45-54.

Darmo, K. K. Y. 2017. Studi Tentang Pembentukan Daerah Otonom Baru ( Dob ) Kabupaten Paser Selatan. Ejournal Ilmu Pemerintahan, 5(1), 353-366.

Diah Rukmawati, I. W. Sudana Dan I. G. J. 2018. Perubahan Paradigma Berotonomi Daerah Pasca Hegemoni Negara Di Kota Denpasar, 1998-2018. Jurnal Ilmu Sosial Dan Ilmu Politik, 9(2), 60-63.

Id, S. 2019. By Rev C.

Kurniawan, H. 2015. Dinamika Proses Pemekaran Kecamatan Pulau Merbau Kabupaten Kepulauan Meranti. Jom Fisip, 2(1), 1-15.

Kurniawan, H. 2015. Dinamika Proses Pemekaran Kecamatan Pulau Merbau Kabupaten Kepulauan Meranti. Journal Jom Fisip, 2(1), 1-15. Https://Doi.Org/10.1017/ Cbo9781107415324.004

Lakip. 2017. Laporan Kinerja Pemerintah Kabupaten Paser. 1-167.

Miller, R. 2015. Natural Resource Extraction And Political Trust. Resources Policy, 45, 165-172. Https://Doi.Org/10.1016/J. Resourpol.2015.04.002

Mirzaqon, A., \& Purwoko, B. 2015. Studi Kepustakaan Mengenai Landasan Teori Dan Praktik Konseling Expressive Writing. 1-8.

Muqoyyidin, A. W. 2013. Pemekaran Wilayah Dan Otonomi Daerah Pasca Reformasi Di Indonesia: Konsep, Fakta Empiris Dan Rekomendasi Ke Depan. Journal Konstitusi, 10(2).

Rifdan. 2010. Implementasi Kebijakan Pemekaran Daerah Dalam Mendukung Integrasi Nasional Di Kabupaten Luwu Timur. Jurnal Administrasi Publik, 1(1).

Rohmah, N. S. 2018. Elit Dan Pemekaran Daerah; KonflikAntar ElitDalam Proses Pembentukan Provinsi Banten. Jurnal Ilmu Pemerintahan, 4(1), 90-105.

Santoso, L. 2012. Problematika Pemekaran Daerah Pasca Reformasi Di Indonesia Oleh: Lukman Santoso (. 1(2).

Simamora, R., \& Halim, A. 2012. Faktor-Faktor Yang Mempengaruhi Pengelolaan Aset Pasca Pemekaran Wilayah Dan Pengaruhnya Terhadap Kualitas Laporan Keuangan Pemerintah Di Kab. Tapanuli Selatan. Jurnal
Ekonomi Dan Bisnis, 10(1), 47-61. Http:// Journal.Unikal.Ac.Id/Index.Php/Ekonomi/ Article/View/338

Supriyadi. 2016. Community Of Practitioners : Solusi Alternatif Berbagi Pengetahuan Antar Pustakawan. Lentera Pustaka, 2(2), 83-93.

Suryawan, I. N. 2018. Pemekaran Daerah Dan Terbentuknya Kelas Menengah ( Baru ) Papua. Jurnal Sosiologi Walisongo, 2(2), 189-202. Https://Doi.Org/10.21580/Jsw.2018.2.2.2961

Suseno, A. 2008. Pemekaran Daerah Dalam Rangka Otonomi Daerah. Skripsi Universitas Airlangga. Http://Lib.Unair.Ac.Id.

Syafa'at, R. 2011. Politik Hukum Dan HakHak Masyarakat Adat Terhadap Akses Sumberdaya Alam. Cakraw Ala Hukum, $V l(2), 77-89$.

Trijono, L. 2011. Reaktualisasi Politik Demokrasi: Politik Agensi Dan Revitalisasi Kelembagaan Demokrasi. Jurnal Ilmu Sosial Dan Ilmu Politik, 15(2), 93-110.

Umar, I., Cangara, H., \& Alam, A. S. 2013. Isu Strategis Komunikasi Politik Di Kalangan Elite Daerah Dalam Proses Pembentukan Kabupaten Luwu Tengah. Jurnal Komunikasi Kareba, 2(4), 335-342.

Wibisono, Y. 2017. Penguatan Fungsi Pengawasan Dewan Perwakilan Daerah Dalam Rangka Proses Demokratisasi Di Tingkat Lokal. Ilmu Dan Budaya, 40(56), 6435-6460.

Yusoff, M. A. 2010. Pilkada Dan Pemekaran Daerah Dalam Demokrasi Local Di Indonesia : Local Strongmen Dan Roving Bandits.

Zebua, B. H. N. 2017. Upaya Pemekaran Provinsi Kepulauan Nias (Studi Kepentingan Elite Politik). JOM Fisip, 4(1), 1-15.

Zuhro, S. 2018. Demokrasi, otonomi daerah dan pemerintahan indonesia. Interaktif Ilmu-Ilmu Sosial, 4(1), 1-28. http://jurnal.umpalembang. ac.id/variahukum/article/view/942/839

BPS. 2019. https://paserkab.bps.go.id/ (diakses pada 04 November 2019)

Prokal. 2019 https://balikpapan.prokal.co/read/ news/116033-dprd-setujui-dob-paser-selatan (diakses pada 04 November 2019)

Tribunnews. 2019. https://www.tribunnews.com/ nasional/2019/08/26/jadi-ibu-kota-baruinilah- profil-dan-kelebihan-kabupatenpenajam-paser-utara-kalimantan-timur (diakses pada 30 Oktober 2019) 
Antaranews. 2019. (https://kaltim.antaranews.com/ berita/9807/paser-tengah-vs-paser-selatanbetulkah-aspirasi-rakyat (diakses pada 30 Oktober 2019)

Antaranewas. 2019. https://kaltim.antaranews. com/berita/16952/massa-pendukung-paserselatan-menginap-di-dewan (diakses pada 30 Oktober 2019)

Antaranews. 2019. https://kaltim.antaranews.com/ berita/16977/dprd-tidak-rekomendasikanpembentukan-kabupaten-paser-selatan (diakses pada 30 Oktober 2019)

Antaranews. 2019. https://kaltim.antaranews.com/ berita/17938/dprd-rekomendasi-pemekarandob-paser-selatan (diakses pada 30 Oktober 2019)

Prokal. 2019. https://kaltim.prokal.co/read/news/41844percepatan-proses-lelang.html (diakses pada 30 Oktober 2019)

Prokal. 2019. https://kaltim.prokal.co/read/news/29510paser-selatan-oke-paser-tengah-setuju (diakses pada 30 Oktober 2019)

Prokal. 2019. https://kaltim.prokal.co/read/news/61727timses-kawal-tahapan-pemekaran-passel (diakses pada 30 Oktober 2019)
Prokal. 2019. https://balikpapan.prokal.co/read/ news/116033-dprd-setujui-dob-paser-selatan (diakses pada 30 Oktober 2019)

Paserkab. 2019. http:/humas.paserkab.go.id/berita/ meskipun-pertumbuhan-ekonomi-paser-turunakibat-batu-bara-pertanian-perdagangan-tetaptumbuhan (diakses pada 25 Desember 2019)

Paserkab. 2020. http://humas.paserkab.go.id/assets/ upload_download/data-wilayah-administrasidesa-kelurahan-di-kabupaten-paser-bulandesember-2018_1508.pdf (diakses pada 7 Maret 2020)

Litbang. 2020. http://kaltim.litbang.pertanian. go.id/ind/index.php?option $=$ com content\&view $=$ article\&id $=424 \&$ Itemid $=\overline{5}$ (diakses pada 7 Maret 2020)

KoranKaltim. 2020. https://www.korankaltim.com/ arsip/paser-selatan-akhirnya-lolos (diakses pada 7 Maret 2020)

Antaranews. 2010. https://kaltim.antaranews.com/ berita/9807/paser-tengah-vs-paser-selatanbetulkah-aspirasi-rakyat (diakses pada 7 Maret 2020) 